УДК 141

DOI 10.35423/2078-8142.2021.1.2.04

А. О.Труфанова, аспірантка кафедри філософіі Донецького начіонального університету,

м. Вінниия, Украӥна e-mail: shelti2008@ukr.net ORCID: https://orcid.org/0000-0003-1110-9186

\title{
ВПЛИВ ГАЙДЕГГЕРА НА ФІЛОСОФСЬКЕ ОСМИСЛЕННЯ КОНЦЕПТУ «МИСТЕЦТВО» ГАДАМЕРОМ
}

У статті робиться спроба аналізу філософського бачення концепту «мистеитва» Гайдеггером та Гадамером. Розглядається репрезентаційність та презентаційність мистеитва з точок зору обох мислителів. Спираючись на онтологічні основи естетичного досвіду, у статті розкриваються основні тези розуміння складових мистецтвва та його характеристик у процесі життєдіяльності історичної спільноти. У філософському баченні Гадамера розглядається герменевтична естетика та розкривається уявлення про мистецтво як про те, що включає гру, символ $і$ фестиваль, аналізується бачення творів мистецтва такими, що існують «y собі». Відтворюється гайдеггерівське розуміння впливу мистеитвва на естетичний досвід історії людства, щчо простежується в його функції «становлення і виявлення істини». Межі нашого розуміння мистецттва та підходу до нього не можуть бути вищими, ніж вони вже існують. Робиться висновок, щчо діалог та інтерпретація є важливими засобами подолання хибних уявлень на шляху до досягнення взаєморозуміння в процесі становлення розуміння кониепту «мистецчтво».

Ключові слова: мистеитво, кониепт мистецтва, Гадамер, Гайдеггер.

(C) Труфанова А. О., 2021 
Швидкоплинний розвиток суспільства вимагає звернення до історичних основ формування підвалин сучасного концепту «мистецтво». Аналіз філософських праць Мартіна Гайдеггера і ГансаГеорга Гадамера дає можливість зробити висновок про глибинність і обгрунтованість їхніх думок, теорій та поглядів на мистецтво. Актуальність філософії Гадамера і Гайдеггера у сучасній Україні зумовлена особливостями пострадянської ментальності, зокрема наголошення на ролі діалогу як засобу долання хибних упереджень на шляху досягнення взаєморозуміння у процесі становлення української модернізованої нації. Філософські традиції обох мислителів докладно розглядаються в наукових працях таких вчених, як О. А. Коваль, Е. Б. Крюкова, Л. А. Мікешина, Л. І. Тетюєв, А. Л. Богачов та ін. Ці наукові дослідження відіграли значну роль у трактуванні і формуванні сучасного концепту «мистецтво» в його історичному ракурсі. Спираючись на бачення М. Гайдеггера і Г.-Г. Гадамера визначних мислителів другої половини XX ст. можна зрозуміти особливу реальність, яку розкриває для нас мистецтво, 3'ясувати і розкрити його смислове, лінгвістичне та естетичне значення, а через критику та аналіз його складових - сформувати власне уявлення щодо прочитання творів мистецтва.

Гадамер навчався філософії в Гайдеггера, коли той викладав у Марбурзькому університеті з 1923 р. Одним з відкриттів благочестивої біографії Жана Грондіна став наступний факт: через рік Гайдеггер послав Гадамеру знищувальний лист, в якому піддав серйозному сумніву здібності і майбутнє молодого філософа. Гайдеггер висловився грубо і різко: «Якщо ви не зможете проявити в собі достатньо жорсткості, з вас нічого не вийде». Як зізнавався сам Гадамер, вердикт Гайдеггера був настільки засуджуючим, що підірвав його віру в себе як філософа на багато років вперед. Гадамер різко відмовився від своїх планів писати дипломну роботу разом 3 Гайдеггером і швидко змінив сферу досліджень 3 філософії на античність. Він зізнавався пізніше, що «Істина і метод» з'явилася так пізно і тому, що Гадамер постійно відчував поруч із собою несхвальну присутність Гайдеггера. Коли в 1928 р. Гайдеггер виїхав 3 Марбурга, щоб замінити Едмунда Гуссерля у Фрейбургзі, Гадамер відчув, що з його плечей впав величезний тягар. Він відчув себе не кинутим, а навпаки - «вільним», як сам зізнавався [2]. Співісну- 
вання двох незалежних філософських поглядів видається важкою справою, коли замість підтримки відчувається осуд. Особливо коли критика йде з боку наставника, з якого ти береш приклад.

До речі, на одному з етапів своєї наукової кар'єри юний протеже Гайдеггера був сповнений гордості за себе, оскільки читав тільки книги, яким виповнилося не менше двох тисяч років [2]. Це ще раз вказує на те, що його вимоги до себе стали дуже високими.

Гадамер поза всяким сумнівом погодився б із твердженням свого філософського вчителя Гайдеггера, який вважав, що сучасне мистецтво і література в основному «руйнівні». В останньому інтерв'ю Гадамер сказав, що велике мистецтво завжди виростає 3 життя «народу» (нім. «Das Volk»). Він хотів таким чином висміяти те, що вважав безвідповідальним космополітизмом естетичного модернізму [2]. Мистецтво відповідає духу часу і тенденцій культури народу, в якому воно бере свій початок. Те, наскільки великим є той чи інший витвір мистецтва, залежить від того, чи може він переростати простір і час, ставати космополітичним і широковідомим за межами місця свого народження.

На сьогоднішній день залишається достатньо спірним питання, чи був Гадамер послідовником Гайдеггера, чи він $є$ оригінальним і самобутнім мислителем. Головним поштовхом до формування філософської системи Гадамера послужила «герменевтика фактичності», генерувати яку Гайдеггер почав задовго до виходу в світ «Буття і часу» (1927) [7, с. 100]. Гадамер не дає уявлення про естетичне в жодному звичному сенсі. Його підхід до мистецтва багато в чому суперечить звичайним філософським очікуванням. Характеристики прекрасного не обговорюються в манері аналітичної традиції сучасної філософії, а також він не зосереджується на проблемах естетичного задоволення. Підхід Гадамера до естетичного досвіду полягає у феноменологічній традиції. Першою чергою підхід стосується місця мистецтва в нашому світовому досвіді. Крім того, його підхід до естетичної теорії - одне з тих рідкісних інтелектуальних досягнень, які одночасно деконструктивні та конструктивні. Він демонтує традиційні елементи платонічної, кантіанської та гегелівської естетики, але все ж пропонує феноменологічну реконструкцію багатьох центральних поглядів цієї традиції, щоб 
продемонструвати її постійне значення для нашого сучасного мистецького досвіду. Гадамер передусім зосереджується на когнітивному вимірі такого досвіду, на тому, чого саме твори мистецтва стосуються і що вони ставлять під сумнів. Це зумовлює гнучкий філософський підхід, здатний вільно змінюватись у низці художніх форм та стилів, обговорюючи як особливості творів, так і їх більш широке значення. Підхід є суто герменевтичним тим, що він прагне познайомити нас з тими отриманими смислами та захопленнями, які лежать в основі нашого мистецького досвіду. Відкрита під впливом Гайдеггера, зокрема його пізніших есе щодо мови та поезії, естетика Гадамера далеко не традиційна. Його основні тези:

1. Естетика - це не вивчення конкретних видів суб'єктивних насолод, що випливають із мистецтва. Це дослідження того, що об'єктивно інформує наше суб'єктивне усвідомлення мистецтва.

2. Герменевтична естетика прагне пробити приємні відволікання естетичної свідомості, щоб розкрити культурні та мовні реалії, які проявляються всередині неї.

3. Герменевтична естетика передбачає феноменологічну причетність до предметів мистецтва, а не незацікавлену відстороненість.

4. Герменевтична естетика розглядає естетичний вигляд не як відволікання від реального, а як засіб, за допомогою якого розкриваються справжні предмети. Це перевертає уявлення про те, що художні твори одразу віддаляються від реальності.

5. Герменевтична естетика є діалогічною. Вона визнає, що практика і теорія розрізняються у висвітленні предмета і спростовують будь-який поділ теорії/практики у галузі мистецтв. Інтерпретація - це засіб реалізації твору.

6. Герменевтична естетика сама по собі не $є$ теорією мистецтва, а сукупністю практичних споглядальних приміток для посилення зустрічі з мистецтвом. Завдання герменевтичної естетики полягає не в тому, щоб досягти концепції мистецтва, а в тому, щоб поглибити наш досвід мистецтва. У герменевтичній естетиці теорія розгорнута для поглиблення споглядання художніх творів, а не для категоризації їх природи.

7. Естетика Гадамера глибоко поважає здатність мистецтва порушувати та оскаржувати звичні очікування. Вона надає етично- 
го значення мистецтву як здатності розкрити обмеження фіксованої культури та відкрити глядача у напряму до іншого та різного [15].

Гадамер наполягає на тому, що картина чи образ, які гідно називати витворами мистецтва, можуть негайно впливати на нас. Мистецтво звертається до нас. Твердження про те, що художній твір «щось комусь говорить» натякає на здивування, шок, а іноді і на розчарування 3 приводу того, що на нього безпосередньо впливає те, що є у творі, і того, що його змушують розмірковувати над своїм твердженням, тому що це стає зрозумілішим як для себе, так і для інших. Гадамер стверджує, що «досвід мистецтва - це досвід смислу, і як такий цей досвід $є$ тим, що викликається розумінням». Тоді до цієї міри «естетика поглинається герменевтикою». Це віддаляє Гадамера від більш звичних виправдань естетики як особливого виду задоволення. Есе «Актуальність прекрасного» свідчить про те, що «простого спостерігача, який віддається естетичним чи культурним насолодам із безпечної відстані, будь то в театрі, концертному залі чи відокремленому самотньому читанні, просто не існує». Людина, яка вважає себе таким спостерігачем, не розуміє себе. «Естетичне саморозуміння потурає ескапізму, якщо розглядає зустріч із твором мистецтва як не що інше, як зачарування у сенсі звільнення від тиску реальності через насолоду фальшивою свободою» [15].

Протистояння Гадамера естетичному ідеалізму підтверджується твердженням, що мистецтво «не можна задовільно перекласти 3 точки зору концептуальних знань». Твір не просто стосується значення, яке не залежить від нього самого. Його значення не слід сприймати таким чином, щоб його можна було просто перенести в іншу ідіому. Справді, оскільки він використовує багато інтерпретацій, твір мистецтва набуває ідеальності можливих значень, яких неможливо уникнути будь-якою можливою реалізацією. Отже, твір має автономію, яку нічим іншим не можна замінити, або, іншими словами, твір завжди перевищує його прочитані значення, значення яких завжди більше, ніж його інтерпретація. Це збігається з тезами Гадамера про те, що Буття перевищує знання, і так само про те, що мовне Буття перевершує мовну свідомість. 
Із цього постає важливий наслідок, а саме: Гадамер сприймає мистецтво як презентаційне (darstellen), а не як репрезентативне (vorstellen). В есе «Слово і малюнок» (1992) він стверджує, що намагається «підірвати думку про те, що картина $є$ просто копією». Оскільки твір не представляє нічого іншого, крім себе, значення, які він несе, можуть виступати лише на перший план у його самопрезентації. Проте значення, що виникає, ніколи не надається в повному обсязі і не усувається будь-яким усвідомленням. Це узгоджується $з$ кінцевим характером мистецтва. «Коли художній твір насправді охоплює нас, це не той предмет, який стоїть навпроти нас, і ми дивимося в надії роздивитися його до передбачуваного концептуального значення. Твір - це Ereigniss, тобто подія, яка «привласнює нас» собі. Це нас поштовхує, збиває і створює власний світ, в який ми втягнуті». Проте те, що розкривається, залишається лише аспектом роботи, який при своїй появі відсуває інші на другий план. Розкриття та прихованість не є протилежними в естетиці Гадамера, але $\epsilon$ взаємозалежні: розкрите виявляє присутність нерозкритого в розкритому. «Саме завдяки знаходженню (Da-sein) художнього твору наше розуміння відчуває глибини та незбагненність його значення».

Репрезентація широко представлена як у філософії, науковому пізнанні, так і в інших формах діяльності, в європейській культурі в цілому. Розглядаючи історію розвитку значення слова «репрезентація», Г.-Г. Гадамер в «Істині і методі» нагадує про його сакрально-правовий сенс: у римлян це слово вживалось в сенсі представництва як платоспроможності, у християнстві репрезентувати означало «здійснювати присутність». Державно-правове поняття репрезентації завжди розуміє під собою «наявність заміщення», і носій суспільної функції - чиновник, депутат і т.д. - як репрезентант виявляється належним «показувати себе таким, як це передбачає його зображення» [10, с. 7].

Проблема репрезентації також обговорюється в контексті розгляду способу буття мистецтва й онтологічного аспекту зображення. Гадамер вважає, що через репрезентацію «зображення набуває свою власну дійсність», «буттєву валентність» і завдяки зображенню першообраз стає саме першообразом, оскільки тільки зображення робить представлене ним власне зображуючим, живописним. Репре- 
зентацію зображення можна зрозуміти як особливий випадок «суспільної події», релігійне зображення отримує значення зразка, а образотворче мистецтво закріплює, а по суті створює ті чи інші типи героїв, богів і подій. У цілому витвір мистецтва мислиться як буттєвий процес, в якому замість абстракцій існують перформанси, ігри, зображення і репрезентації, зокрема у вигляді знаків і символів, які дають можливість чомусь «бути в наявності» [3].

У традиційному епістемологічному сенсі репрезентація - це одна 3 фундаментальних операцій будь-якої пізнавальної діяльності, що спирається на представленні ідеальних і матеріальних об'єктів в акті свідомості і знання з допомогою їх «заступників» або «посередників» - символічних, знакових, першою чергою мовних систем, моделей, будь-яких «когнітивних артефактів», а також матеріальних об'єктів, що виконують ці функції [10, с. 8].

У Декарта, як відзначив М. Гайдеггер, головною стає саме репрезентація - можливість представити як протиставити, помістити перед собою наявне суще, включити його у відношення із собою як предмет. Якщо звернутися до глибинних сенсів слова «презентація», що достатньо стерлося, то, як показав Гайдеггер, воно означає поставлення перед собою і в відношення до себе». За цим стоїть перетворення світу в картину, точніше - розуміння світу в сенсі картини, що, своєю чергою, тягне перетворення людини на суб'єкт. Тепер людина не так вдивляється в суще, як уявляє собі картину сущого, і вона стає об'єктом дослідження, інтерпретованою ре-презентацією цього сущого. «Пред-ставити означає тут помістити перед собою наявне». «Усе присутнє отримує від свідомості сенс і образ своєї присутності, а саме презентності всередині repraesentatio». «...Мислення вручає нам присутнє, відновлює його у відношенні до нас. Тому пред'явлення (наявного. Л. М. Мікешина) - це ре-презентація... Чому представлення - це ре-презентація?» Проблема репрезентації залишається, а «філософія поводить себе так, ніби тут ні про що запитувати» - відзначає Гайдегер у статті «Що значить мислити?» [14].

Отже, перетинаються два процеси: світ перетворюється на поставлений перед людиною предмет (об'єкт), а людина стає суб'єктом, репрезентантом, що розуміє свою позицію як світогляд, 
як представлення картини світу 3 позиції візуальної метафори. Гайдеггер вважав, що репрезентація не представляє собою первинний доступ до світу, це вже інтерпретація, «всяке допредикативне просте бачення підручного саме по собі вже розуміюче і пояснююче... Зір цього перегляду завжди є таким, що розуміє і пояснює» [14]. Це певний результат рефлексивної і розуміючої діяльності; безпосередньо світ нам доступний лише в практичних діях повсякденного життя, не всі $з$ яких можуть бути експліковані і потребують спеціальної мови. Відповідно, пізнання, включаючи репрезентацію як процедуру i, через неї, пізнання, яке пояснює самі «механізми», вже «навантажено» тим, що передбачає визнання «оптичної теорії пізнання», візуальної метафори, метафори дзеркала і панування зорового сприйняття у формуванні знання [10, с. 9].

Мартін Гайдеггер звернув увагу на те, що новоєвропейське тлумачення сутнього як представленого, а отже, протиставленого людині в суб'єкт-об'єктному розрізненні (завдяки чому «світ перетворюється на картину»), зумовлює істотну зміну в семантиці поняття «репрезентація», яке тепер протиставляється «присутності» (самому буттю), презентації (раніше його розуміли саме як різновид присутності) й наближується до значення «представлення (уявлення)» як суб'єктивної апперцепції [14, с. 50]. Натомість у герменевтичній естетиці Г.-Г. Гадамера поняттю репрезентації повертається його традиційний онтологічний статус. На думку Гадамера, поняття репрезентації означає «буттєву валентність» художнього зображення, онтологічну співвіднесеність образу і першообразу [3, с. $137 ; 6$, с. 131].

Жоден сенс не може бути повністю розкритий. Оскільки ми можемо повторно пізнавати твори мистецтва, значення, розкрите спочатку, може бути розширене або змінене. Частковий характер будь-якого розкриття сенсу збільшує, а не зменшує можливість значення у творі.

Розмова про естетику Гадамера стосується і сміливіших аспектів: мистецтво є запитувальним за своєю природою, твори працюють шляхом розкриття значення, розкриття значення встановлює когнітивний статус мистецтва, пізнавальний зміст мистецтва частково зрозумілий і частково загадковий, і твори мистецтва завжди відкриті для повторної інтерпретації. Однак це не визначені 
аргументи. Позиція Гадамера є герменевтичною не через основну тезу, яка залишається без зауважень, а тому, що вона формується сукупністю різноманітних аргументів, що формують центральну позицію.

Розкриття онтологічних основ естетичного досвіду не підриває першості, яку Гадамер надає безпосередньому зверненню до мистецтва. Мета полягає в тому, щоб продемонструвати когнітивну легітимність суб'єктивного досвіду, виявивши, як естетичний досвід одночасно бере участь у чомусь більшому, ніж він сам, i, справді, відображає (speculum) цю більшу актуальність у собі [16]. Здатність естетичного досвіду виражати транс-індивідуальні феноменологічні структури пояснює, що розуміється під субстанці$€ ю$, та його спекулятивне ставлення до неї. Естетика Гадамера належним чином переживає те, що лежить в основі їі більш абстрактних концепцій. Йдеться не про те, щоб назвати або описати реальність, яка проявляється в естетичному досвіді, а про те, щоб спробувати сказати щось про індивідуальний досвід, який отримує в ньому людина. Роздуми Гадамера починаються з безпосередності висловлювання тверджень про мистецтво, їх одночасного характеру, а потім досліджень, що впливають на досвід усвідомлення цих тверджень.

3 усіх речей, що говорять 3 нами, саме твір мистецтва робить це найбільш безпосередньо. Феноменологічна безпосередність мистецтва, що ініціює герменевтичне дослідження Гадамера щодо естетичного досвіду, може здаватися не перспективною відправною точкою 3 точки зору герменевтики. Він декларує нетрадиційний герменевтичний підхід до мистецтва, відзначаючи, що якщо визначити завданням герменевтики подолання особистої чи історичної відстані між розумами, то досвід мистецтва, як здається, повністю виходить за межі свого (герменевтичного) походження. Однак Гадамер не визначає герменевтику таким чином. Об'єктом його дослідження є не реконструкція художнього задуму, а питання безпосередності звернення до твору мистецтва. Художній твір $\epsilon$ об'єктом герменевтичного дослідження не через своє значення першоджерела у психологічних подіях, а через те, що він передає нам певну інформацію. 
Герменевтика Гадамера - філософське прояснення розуму, яке він тлумачив як рух і втілення історичної традиції, завершеного в собі космосу. Гадамер заперечував суб'єктивістські естетичні концепції, згідно з якими значення твору зводиться до вражень (уявлень, почуттів, настроїв), що $є$ суто індивідуальними, суб'єктивними. Мистецький твір долучає нас до істини, відкриваючи перспективи нашого власного буття; він не є прихованою алегорією, яка вказує на щось наявне. Мистецтво - не відображення наявного, а нарощення наших смислів (буття) шляхом відкриття екзистенційних перспектив. Гадамер вказував, що розуміння мистецького твору через пояснення обставин його створення виконує допоміжну роль; найважливіше у творі те, що він «промовляє» саме до нас, сучасний нам. Істину, відкриту твором мистецтва, Гадамер пояснював через поняття «алетея» - неприхованість буття; твір мистецтва - гра прихованого та неприхованого. Поняття «гра» центральне в естететичній герменевтиці Гадамера. Мистецтво - це гра, символ і фестиваль. Мистецький твір «виводить» за межі нашої зануреності у буденність, тому зустріч із твором мистецтва $\epsilon$ фестивалем [1].

Розповідь Гадамера про символ вказує на те, що твори мистецтва $є$ презентаційними, а не репрезентативними. Презентації мають на увазі значення, на які вони посилаються, і не представляють значення, незалежного від них самих. Аргумент впливає на глибоку і значну зміну значення естетичного вигляду. Репрезентативний погляд на мистецтво відводить мистецтво до другорядного статусу: твір нагадує щось інше, крім твору мистецтва, оригінальний стан справ, конкретний сенс чи реальність. Відповідно, об'єктивна співвідносність мистецтва розміщується поза твором так, що твір стає простим проявом чогось іншого. Презентаційний виклад мистецтва відповідає феноменологічній спрямованості Гадамера. Якщо значення, на яке посилається твір, не є незалежним від твору, який його викликає, твір є приводом для появи цього значення. Поява стає синонімом первозданного творіння. Естетичний вигляд не $\epsilon$ другорядним щодо реальності чи істини, а $є$ середовищем, засобом, за допомогою якого істина твору показується / представляється. Навіть як презентація, зовнішній вигляд зберігає певний негатив, хоча в руках Гадамера він має позитивні якості. 
Зовнішній вигляд завжди натякає на подобу чогось неповного або ще не повністю усвідомленого. Онтологія Гадамера відкрито посилює, якщо не вимагає такого негативу. Твердження про те, що кожен витвір мистецтва має власну тимчасовість, означає, що кожен 3 них ніколи не розкриє себе повністю. Твердження про те, що рецепція всього мистецтва є одночасною, диктує, що те, що представляється нам значущим, не обов'язково є значущим для попереднього покоління. Як і символ, зовнішній вигляд завжди частковий. Однак зовнішній вигляд, якщо розглядати його естетично, має ритм символічного: він натякає на щось поза собою, але тим не менш щось усередині нього $є$ ще не відкритим.

Такі аргументи підтверджують уявлення Гадамера про твір мистецтва як про такий, що існує у собі. Те, що з'являється, стає зрозумілим як подання певного значення, але через невизначеність цього значення воно зберігає щось загадкове. Цю видатну якість (справжній твір ніколи не можна порівняти з оригінальним способом його демонстрації) - Гадамер також називає герменевтичною ідентичністю. Істинність твору мистецтва полягає не в його простому вияві значення, а в нерозбірливості та в глибині його значення. Його істина охоплює напругу між одкровенням (те, що 3'являється), і тим, що приховується (те, що ще має бути показано). Твір не просто пропонує «впізнаваний поверхневий контур», але має внутрішню глибину самодостатності, яку Гадамер називає вже після Гайдеггера «існуючою в собі». Тож, особлива ознака змістовної роботи полягає в тому, що вона завуальовує можливості смислу. Такий опір є стимулом для подальшої інтерпретації. Змістовні твори, як і значущі символи, мають непрозорий аспект.

Є деякі відмінності в розумінні у Гайдеггера і Гадамера. Якщо для раннього Гайдеггера розуміння здійснюється як взаємодія Dasein 3 внутрішньо світовим сущим у процесі його практичного освоєння, то Гадамер вважає найкращим зразком зустріч «події розуміння» 3 твором мистецтва. I той, і інший досвід мають мало спільного $з$ традиційним уявленням про розуміння як суто раціональну активність, однак інтуїтивна природа розуміння в разі переживання художнього творіння, сприйняття якого передбачає незацікавленість, явно відрізняється від прагматичного, діяльнісного ро- 
зуміння при обживанні у світі. Мистецтво приваблює нас не своєю корисністю: воно зухвало неутилітарне і ні для чого не придатне. Але його інакшість, незрозумілість - нехай навіть як провокація залишається адресованим нам питанням, відповідь на яке вимагає особистої участі. Необхідність відповідати - у сенсі як «тримати відповідь», так і «відповідати на виклик» - відтворює найпростішу діалогічну структуру, яка і породжує взаєморозуміння. Хоча може здатися, що взаєморозуміння 3 твором мистецтва $є$ не більше ніж метафорою, оскільки передбачає як мінімум двох повноцінних співрозмовників, однак Гадамеру важливо підкреслити особливий спосіб існування, скажімо, літературного тексту, який не менш активний, ніж процес читання. Естетичне розуміння як взаєморозуміння реалізується не в суб'єктно-об'єктних відносинах; артефакти в якості повноправних учасників події, яка здійснюється, виявляються своєрідним дзеркалом, в якому глядачу відкривається правда про себе самого, «щось інше, чим своє власне» [7, с. 106]. Символ та його стриманість щодо розкриття прихованих аспектів його значення не означають щось абсолютно чуже для нас. Ще не розкритий - це вимір сенсу, який пропускають, забувають або не сприймають у межах того, що вже було показано або зрозуміло. Іншими словами, сила символу полягає в його здатності розкрити те, що, непомітно для нас ми перебуваємо у спілкуванні з чимось набагато більшим, ніж ми самі, тобто з горизонтами значення, які неявно підтримують рефлексію і які можуть, будучи явними, змусити нас думати про себе зовсім інакше. Таємницею символу $є$ його обіцянка переваги: ефективний і дієвий символ виявляє, що ми належимо до герменевтичної спільноти, завжди більшої, ніж ми передбачаємо. Аналогія фестивалю, знов таки, є показовою. На фестивалі відмовляються від індивідуальних робочих ролей, оскільки заново відкривають суспільні і зв'язки. Таким чином аргументи Гадамера щодо гри, фестивалю та символу є основою для його твердження, що естетичний досвід, наш досвід мистецтва $\epsilon$ наочним прикладом того, як суб'єктивність інформується субстанціональністю, що перевищує індивідуальну свідомість.

Як відомо, в «Істині і методі» Гадамер розкриває онтологію і герменевтичний сенс твору мистецтва через роз'яснення феноменів гри і свята [3, с. 145]. Почнемо з герменевтичного тлумачення тво- 
ру мистецтва, в якому гра визначається як «справжня нитка Аріадни онтологічної експлікації». Гадамер, на противагу естетичній суб'єктно-орієнтованій настанови, підкреслює вкоріненість твору мистецтва у світі, що існує до і поза рефлексивним суб'єктом і його цілеспрямованою діяльністю. Гра в такому розумінні - це не результат взаємодії гравців, але «буття гри» є «незалежне від свідомості гравців» [3, с. 147]. Показовими щодо цього є приклади, які він наводить для роз'яснення онтологічного виміру гри: це гра світла і тіні, хвиль, тварин і т.д. Залучена у гру дорефлексивна десуб'єктована реальність має первинний характер стосовно гравця: не гравець грає у гру, а реальність гри створює ігровий простір і конституює нового суб'єкта - гравця. Відзначимо незвичне і парадоксальне для суб'єктно-орієнтованої естетичної свідомості Гадамерове зіставлення природності гри для тварин і природи i «неприродності» гри для людини: «Справа явно йде не таким чином, що тварини теж грають і що навіть про воду і світло можна в переносному значенні сказати, що вони грають. Швидше, навпаки, про людину можна сказати, що навіть вона грає» [3, с. 150]. Тим самим Гадамер підводить нас до думки про медіальний характер гри і твору мистецтва, їх спосіб буття - самопрезентація, яка вперше дає світу і буттю можливість саморозкритися і самовиявитися так, як ніколи і ніде раніше. Щодо цього твір мистецтва визначається як різновид гри, властивої людині, як подія занурення в онтологічний вимір досвіду світу. Саме тому Гадамер називає перетворення гри на мистецтво перетворенням на структуру і тотальним опосередкуванням: у творі мистецтва більше немає гравця, залишається тільки те, що грає. Відповідно, прекрасне розуміється не як ефект сприйняття суб'єктом твору мистецтва, а як спосіб буття, що репрезентує універсальну онтологічну структуру: «Спосіб буття прекрасного виявився для нас знаком загального буттєвого устрою» [3, с. 561]. Гадамер відзначає цей специфічний спосіб буття твору мистецтва, наслідуючи думки Платона: «Безперечно, відмітна риса прекрасного в порівнянні з благом - те, що воно виявляє себе із себе самого, робить себе безпосередньо очевидним у своєму бутті» [3, с. 555]. До того ж таке самовиявлення не можна розуміти як якесь цілеспрямоване, навмисне самопоказування, демонстрацію для того, щоб 
всі це побачили. Це несвідомо (чи безсвідомо) сконструйована штучна реальність (ілюзія), яку демонструють на показ. Виявлення себе із себе самого - це спосіб буття твору мистецтва, інакше бути воно не може. I, одночасно, це справді феноменологічна даність буття: буття виявляє себе (відповідно, вбачається) у творі мистецтва не через якесь інше суще, а через саме себе, тобто очевидно являючи саме себе, самоявляючись. «Прекрасне, спосіб виявлення благого, саме робить себе явним, розкриває себе у своєму бутті, саме себе перед’являє, представляє, презентує (darstellt). Те, що таким чином презентується, у своїй представленості не відрізняється від себе самого. Воно не $\epsilon$ щось одне для себе і щось інше для інших. Воно не є також чимось в чомусь іншому» [3, с. 561]. Відповідно, герменевтична інтерпретація феномена свята покликана роз'яснити темпоральність твору мистецтва і його світовий, універсальний, онтологічний характер.

У своїй праці «Мистецтво і наслідування» Гадамер, розглядаючи проблему сучасного живопису, аналізує три поняття: наслідування, вираження і поняття знаку і мови знаків. Перше поняття поняття наслідування, на його думку, збігалося із вченням про мистецтво як наслідування природі. Це пов'язано з нормативними уявленнями, наприклад, про те, що мистецтво завжди дає право очікувати від нього певною мірою правдоподібності. Поняття пережило свій справжній естетичний і художньо-політичний розквіт у французькому класицизмі XVII - початку XVIII ст. і вплинуло на німецький класицизм. Вимога, щоб мистецтво не переступало меж правдоподібного, переконання, що в ідеальному художньому творі перед нашим духовним поглядом виступають образи самої природи в їх чистому прояві, віра в ідеалізовану силу мистецтва, що додає природі iї справжню завершеність, - ось відомі уявлення, що входять у термін «наслідування природі». Філософ наголошував, що ми виключаємо при цьому тривіальну теорію крайнього натуралізму, згідно з якою весь сенс мистецтва полягає у звичайному уподібненні природі. Друге поняття - поняття вираження - постало і утвердилося проти поняття наслідування в XVIII ст. Більше всього це простежується на прикладі музичної естетики. Музика рід мистецтва, в якому концепція наслідування, звичайно, найменш очевидна і більш всього обмежена у своїй застосовності. То- 
му в музичній естетиці XVIII ст. поняття вираження усталюється, щоб у XIX i XX століттях, не зустрічаючи опору, утвердитися в сфері естетичної оцінки [12]. Виразна сила і виразна справжність того чи іншого способу виступають як виправдання художнього повідомлення, що міститься в образі. Саме так вважає масова свідомість, але постає питання, що таке кітч (нім. kitsch - халтурка, відсутність смаку, «дешева річ»), який має проникливу виразну силу і художня недійсність якого явно не суперечить суб'єктивній автентичності почуття у виробника або споживача. Однак перед обличчям того краху форм, яким нас обдарувала сучасність і внаслідок якого ідеалізована картина природи і експресивна душевність більше не становлять змісту художнього образу, поняття вираження, як і поняття наслідування, схоже, вже не працює. І третє поняття - поняття знаку і мови знаків. У цього поняття теж поважна історія. На ранньому початку християнської епохи виправданням мистецтва була його роль Біблії бідних (лат. biblia pauperum) для неписьменних людей, роль зображення і прославлення священної історії і благої вісті. Тоді сприйняття мистецтва зводилося до прочитання певного ланцюжка відомих історій. Подібного прочитання вимагають, схоже, і модерністські зображення, тільки прочитання не образів, а знаків, як при читанні листа. Знаки цього листа, звичайно, не належать, попри всю абстрактність свого змісту, до особливого виду букв. Але, однак, певна схожість має місце. Винахід буквеного письма уможливив неймовірне: фіксувати в декількох абстрактних значках, що піддаються раціональній комбінаториці, яку ми називаємо орфографією, все, що проходить через розум людський, - справді одна 3 найбільш революційних подій у людській культурі. Дещо з давніх часів перейшло і в нашу манеру розглядати зображення. Так, ми «прочитуємо» кожну картину зверху зліва вниз направо i, як відомо, перевертання по типу дзеркального відображення справа наліво, легко здійсненне сучасними засобами технічного відтворення, призводить (як стверджує Генріх Вельфлін) до найхимерніших композиційних викривлень і спотворень. Ще значно більше від цих наших навичок письма і читання перейшло схожого на той вид образного письма, в якості якого ми намагаємося прочитати модерністські полотна: ми вже не бачимо в них 
збереження цілісності образу відображень, зміст яких можна було б упізнати. Імовірніше, на цих картинах якимись ієрогліфічними знаками і штрихами просто записано, тобто розміщено в ряд, те, що слід сприйняти одне за другим по порядку і в підсумку сплавити воєдино, пригадуючи, скажімо, картину Малевича «Дама в місті Лондоні», де можна ще цілком чітко розпізнати принцип розпаду форми в його психологічному варіанті. Окремі сутності, які сприймає зображена жінка, мабуть, зовсім збентежена скромним вуличним рухом 1907 р., - цілий потік відокремлених вражень, які немов беруться до уваги і підсумовуються в одне образотворче ціле. Глядачеві, спостерігачеві, споглядачу доручається синтезування всіх цих аспектів і граней. Про існування такого формального принципу нам говорить манера, скажімо, Пікассо і Хуана Гріса, яка розшаровує, деталізує. Тут є ще й пізнання, але усе знання незмінно поглинається тією самою єдністю картини, яка більше не об'єднується в таке наочне ціле, що піддавалося б формулюванню з боку свого образного сенсу. Це образне письмо, що становить, подібно до певної стенограми, композиційний елемент образної композиції, зіставляється 3 відторгненням сенсу. Тому поняття знака втрачає свою власну визначеність; і справді, вимога прочитання подібного сучасного образотворчого письма з часів кубізму поступово затихає [8]. Гадамер доходить висновку, що «у трьох окреслених ним естетичних категоріях можна знайти крихту вірного і адекватного, але вони в жодному разі ще не дають відповіді на те специфічно нове, що ми відчуваємо в мистецтві нашого століття» [4, с. 229-232].

Формулюючи універсальну естетичну категорію, Гадамер спирається на стародавнє поняття мімезиса, яке передбачає представлення порядку. «Засвідчення порядку - ось, мабуть, те, що від століття до століття і завжди є значущим; кожний справжній витвір мистецтва навіть у нашому світі, який дедалі більше змінюється в напряму уніформності і серійності, засвідчує духовну впорядкувальну силу, що становить існуюче, початок нашого життя. У творі мистецтва зі зразковою ясністю відбувається те, що робимо всі ми, оскільки є присутніми: постійно сповіщаємо світ». У нашому мінливому світі художній твір є зразком порядку. У роботі художників і в досвіді мистецтва споглядається те, що й відбувається 
протягом становлення всієї людської культури - «ми впорядковуємо те, що у нас розпадається» [4, с. 241].

Для Гадамера мистецтво є видом пізнання, а витвір мистецтва - своєрідною трансцендентальною умовою долучення до цього виду пізнання, перетворюючи собою суб'єкта долучення. Більше того, безпосередня чуттєво-споглядальна зустріч з твором мистецтва служить підставою естетичного досвіду. У цьому він вбачає далекоглядний герменевтичний наслідок: «будь-яка зустріч 3 мовою мистецтва $\epsilon$ зустріччю з незамкнутою подією і навіть $\epsilon$ частиною цієї події» [3, с. 144]. Кожен твір мистецтва являє себе завжди у вигляді власного Präsenz - справжнього відтворення. «Одночасність» - умова, за якою твір мистецтва знаходить своє існування, що перебуває по той бік часу. Усупереч історії створення твору мистецтва йому притаманний вимір «абсолютного теперішнього» (absolute Gegenwärtigkeit): воно має власну конкретну тимчасовість і специфічну актуальність і тим самим зберігає в собі момент критики розуміння і можливість постійного оновлення мистецького досвіду. Воно відкрито світу як «універсум сенсу». «І хіба завдання естетики, - запитує філософ, - полягає не в тому, щоб обгрунтувати те, що пізнання мистецтва - це тип пізнання свого роду, що ймовірно відрізняється від типу чуттєвого пізнання, яке постачає науці кінцеві дані, на яких вона грунтує пізнання природи, але також цей тип пізнання відрізняється і від морально-розумного пізнання і взагалі від будь-якого понятійного пізнання, залишаючись все ж пізнанням, тобто опосередкуванням істини?» [3, с. 143]. Естетична герменевтика Гадамера перебуває в опозиції до теорії відображення, яку тривалий час вважали основою пояснення мистецької творчості [5].

Щоб зрозуміти критику Гайдеггера щодо естетики, потрібно спочатку сформулювати його позитивний погляд на справжню історичну роль мистецтва. Власне розуміння Гайдеггером твору мистецтва $є$ рішуче популістським, але з революційними прагненнями. Він вважає, що в найвищому значенні мистецтво «засновує історію», «даючи істині можливість проростати». Великі твори мистецтва працюють на другому плані наших історичних світів, іншими словами, частково втілюючи i, таким чином, вибірково підси- 
люючи імпліцитне відчуття історичної спільноти про те, що існує $і$ що має значення. Таким чином, великі твори мистецтва 1) «спочатку надають речам свого вигляду», тобто допомагають встановити імпліцитне уявлення історичної спільноти про те, що існує, і 2) надають «людству свій погляд на себе». Тобто вони також допомагають сформувати імпліцитне відчуття історичної спільноти про те, що справді має значення в житті (а також і про те, що ні), які типи життя є найбільш вартими, які дії $є$ «благородними» (або «низькими»), що у традиціях громади найбільше заслуговує на збереження тощо. Як випливає з цього, Гайдеггер погоджується $з$ вченням про онтологічну історичність (уточнюючи точку зору, вперше розроблену Гегелем) [15]. Іншими словами, Гайдеггер вважає, що фундаментальний досвід реальності людства змінюється з часом (іноді різко), і він припускає, що твір мистецтва допомагає пояснити основний механізм цієї історичної трансформації зрозумілості. Оскільки великі твори мистецтва непомітно створюють, підтримують та трансформують історично мінливе уявлення людства про те, що існує і що має значення, Гайдеггер підкреслює, що «мистецтво - це становлення і виявлення істини». Тобто великі твори мистецтва допомагають встановити імпліцитну онтологію та етику, завдяки яким історична спільнота розуміє себе та свій світ. Підводячи підсумок, великі мистецькі роботи створюються шляхом вибіркового фокусування негласного відчуття історичної спільноти про те, що існує і що має значення, і відображення його назад тій спільноті, яка, таким чином, імпліцитно розуміє себе у світлі цього твору мистецтва. Таким чином, твори мистецтва функціонують як онтологічні парадигми, слугуючи своїм спільнотам «взірцями» реальності, а це означає (як красиво висловлюється Дрейфус), що твори мистецтва можуть по-різному «проявляти», «формулювати» або навіть «переконфігуровувати» історичні онтології, що підтримують їх культурний світ.

Також Гайдеггер припускає, що мистецтво може виконувати свою роботу, розкриваючи світ, відіграючи свою роль, принаймні в трьох різних видах: 1) мікропарадигми, які він пізніше називатиме "речовими речами", які допомагають нам усвідомити, що найважливіше для нас; 2) парадигматичні твори мистецтва, такі як живопис Ван Гога та поезія Гельдерліна, які розкривають, як працює 
саме мистецтво; та 3) макропарадигматичні «великі» твори мистецтва, такі як грецький храм і трагічна драма (твори, які Гайдеггер також іноді називає «богами»), які досягають фундаментальної трансформації «розуміння буття» історичної спільноти, їі найосновнішого і остаточного розуміння того, що існує і що має значення. Саме з урахуванням цього онтологічно революційного потенціалу великого мистецтва Гайдеггер пише: «Щоразу, коли трапляється [велике] мистецтво - тобто, коли є початок - поштовх, що входить в історію, історія або запускається, або починається спочатку». Тобто, велике мистецтво здатне подолати інерцію існуючих традицій і зрушити взаємопов'язані онтологічні та етичні колеса історії, або даючи нам нове відчуття про те, що існує, і що має значення, або ж принципово перетворюючи усталену онтологію та етику, завдяки яким ми створюємо своє відчуття світу і нас самих. Таким чином, враховуючи погляд Гайдеггера на, без перебільшення сказати, революційну роль, яку мистецтво може зіграти непомітно формуючи та трансформуючи наше основне відчуття того, що існує і що має значення, його зрідка недоброзичлива критика зведення мистецтва до естетики стає значно легшою для розуміння. Оскільки, на його думку, межі в нашому розумінні мистецтва та підході до нього не можуть бути вищими, ніж ті, що вже існують [17].

Мистецтво і філософія роблять одну спільну справу, а саме виводять істину з таємничості і виявляють іï світу. Величезна різноманітність пропонованих поглядів на концепт «мистецтва» і на герменевтичний сенс творів мистецтва має на меті змусити нас замислитися. Неможливо не задатися питанням чи $є$ вони в якомусь сенсі спробами роз'яснити одні і ті ж культурні звичаї або звернутися до однієї і тієї ж проблеми культурного і духовного розвитку нації.

\section{ЛIТЕРАТУРА}

1. Богачов А. Філософська герменевтика. К., 2006.

2. Волин Ричард. Оправдание Сократа. Замечательная и ужасная жизнь Ганса-Георга Гадамера. URL: https://web.archive.org/web/200709 27002943/http://left.ru/2003/17/gadamer93.html 
3. Гадамер Г. Г. Истина и метод, Основы философской герменевтики. М., 1988. 704 с.

4. Гадамер Г. Г. Искусство и наследование. Актуальность прекрасного. М. : Искусство, 1991. С. 228-241.

5. Гадамер Ганс-Георг. Енциклопедія сучасної України. URL: http://esu.com.ua/search_articles.php?id=25464

6. Головей В. Становлення концепту репрезентації у філософськоестетичному дискурсі. Науковий вісник Чернівецького університету. Збірник наук. праць. Вип. 726-727. Філософія

7. Коваль О. А., Крюкова Е. Б. Путями герменевтики Хайдеггера и Гадамера. Философский журнал. 2015. Т. 8. № 4. С. 99-108.

8. Критичне зауваження Пікассо про пізнього Хуана Гриса у Канвайлера (Kahnweiler D. И. Juan Gris. Sa vie, son oeure, ses ecrilis Paris, 1946).

9. Лаврухин А. В. Феномен искусства в философии Г. Г. Шпета и Г. Г. Гадамера. Вестник Томского государственного университета. Философия. Сочиология. Политология.

10. Микешина Л. А. Репрезентация: частный метод или фундаментальная операция познания. Эпистемология \& Философия науки. 2007 T. XI. № 1.

11. Тетюев Л. И. Философия языка Ханса-Георга Гадамера и его опыт интерпретации произведения искусства. Изв. Сарат. ун-та. Нов. сер. Сер. Философия. Психология. Педагогика. 2017. Т. 17. Вып. 3.

12. Фубини. Музыкальная эстетика с ХVIII века до сегодня (Fubini M. L'esietica musicale da! Settecento a oggi, 1964).

13. Хайдеггер М. Бытие и время / пер. с нем. В. В. Бибихина. Харьков : Фолио, 2003.

14. Хайдеггер М. Время картины мира. Марин Хайдеггер. Время и бытие: статьи и выступления / пер. с нем. В. В. Бибихина]. М. : Республика, 1993. С. 41-62. Статьи и выступления. М., 1993. С. 49-51, 60-61.

15. Хайдеггер М. Что значит мыслить? Хайдегzер М. Разговор на проселочной дороге. Избр. статьи. М., 1991. С. 143-144.

16. The Stanford Encyclopedia of Philosophy: Gadamer's Aesthetics. URL: https://plato.stanford.edu/entries/gadamer-aesthetics

17. The Stanford Encyclopedia of Philosophy: Heidegger's Aesthetics. URL: https://plato.stanford.edu/entries/heidegger-aesthetics 


\section{REFERENCES}

Bogachev, A. (2006). Philosophical hermeneutics. Kuiv. [In Ukrainian].

Wolin, Richard. Justification of Socrates. The wonderful and terrible life of Hans-Georg Gadamer. Retrieved from: https://web.archive.org/web/200709 27002943/http://left.ru/2003/17/gadamer93.html [In Russian].

Gadamer, G. G. (1988). Truth and Method, Fundamentals of Philosophical Hermeneutics. Moscow. [In Russian].

Gadamer, G. G. (1991). Art and Inheritance, The relevance of beauty (pp. 228241). Moscow: Iskusstvo. [In Russian].

Gadamer, G. G. Encyclopedia of modern Ukraine. Retrieved from http://esu.com.ua/search_articles.php?id=25464 [In Ukrainian].

Golovey, Victoria. Formation of the concept of representation in philosophical and aesthetic discourse. Lesia Ukrainka East European National University, Lutsk. Scientific Bulletin of Chernivtsi University. Collection of scientific works № 726-727. Philosophy. [In Ukrainian].

Koval, O. A, Kryukova, E. B. (2015). By the ways of Heidegger and Gadamer hermeneutics. Philosophical Journal. Book 8(4) (pp. 99-108). [In Russian].

Kahnweiler, D. I., Juan, Gris. (1946). Picasso's critical remark about the late Juan Gris in Canvailer. Sa vie, son oeure, ses ecrilis Paris.

Lavrukhin, A. V. The phenomenon of art in the philosophy of Shpet and Gadamer. Bulletin of Tomsk State University, Philosophy. Sociology. Political science [In Russian].

Mikeshina, L. A. (2007). Representation: a particular method or a fundamental operation of cognition. Epistemology \& Philosophy of Science, XI(1). [In Russian].

Tetyuev, L. I. (2017). The philosophy of the language of Hans-Georg Gadamer and his experience of interpreting a work of art. News of Saratov University. New series. Series. Philosophy. Psychology. Pedagogy, 17(3). [In Russian].

Fubini. (1964). Musical aesthetics from the eighteenth century to the present. In Fubini, M. L'esetica musicale dal! Settecento a oggi.

Heidegger, M. (2003). Being and time. V. V. Bibikhin (Trans). Kharkiv: Folio. [In Russian]. 
Heidegger, M. (1993). Time of the picture of the world. In Marin Heidegger. Time and being: articles and speeches of Marin Heidegger. V. V. Bibikhin (Trans). (pp. 41-62. Articles and speeches; 49-51, 60-61). Moscow: Respublika. [In Russian].

Heidegger, M. (1991). What does it mean to think? In He is. Conversation on a country road. Select articles (pp. 143-144). Moscow. [In Russian].

The Stanford Encyclopedia of Philosophy: Gadamer's Aesthetics. Retrieved from https://plato.stanford.edu/entries/gadamer-aesthetics

The Stanford Encyclopedia of Philosophy: Heidegger's Aesthetics. Retrieved from https://plato.stanford.edu/entries/heidegger-aesthetics

\title{
Anna Trufanova
}

Post-Graduate Student of the Department of Philosophy, Donetsk National University; Vinnytsia, Ukraine; e-mail: shelti2008@ukr.net; ORCID: https://orcid.org/0000-0003-1110-9186

\section{Heidegger's influence on the philosophical understanding of the concept of "art" by Gadamer}

\begin{abstract}
The author of the article analyzes the philosophical vision of the concept of "art" by Heidegger and Gadamer, gives comparative characteristic and reveals the meaning of how their vision of art has changed in different historical periods. Representativeness and presentability of art are considered from the point of view of both philosopher's. Based on the ontological foundations of aesthetic experience, the article reveals the main theses of understanding the components of art and its characteristics in the process of life of the historical community. Gadamer's philosophical vision examines hermeneutic aesthetics and reveals the definition of art as one that includes play, symbol, and festival, and analyzes the vision of works of art as existing "in themselves". Haidegger's understanding of the influence of art on the aesthetic experience of human history is reproduced, which is based on its function of "formation and discovery of truth". To encounter the paradoxical movement at rest within a great artwork, Heidegger believes we need only follow the phenomenological dictum that we should "simply describe" our experience of the work of art "without any philosophical theory". The author argues that Gadamer is not applying a
\end{abstract}


hermeneutic method to aesthetic experience but seeking to expose the hermeneutical movement from part to whole within aesthetic experience. In other words, the claim that aesthetics should be taken up within hermeneutics is not an attempt to reduce aesthetics to another idiom. It announces an endeavor to articulate the hermeneutic dynamic of aesthetic experience itself. The tension in Gadamer's position arises from asserting art's autonomy and demanding that aesthetics be subsumed within hermeneutics. By analyzing the philosophical vision of art in the works of Heidegger and Gadamer, understanding its essence appears in the prism of the modern vision of the concept of art. The boundaries in our understanding of art and approach to it cannot be higher than it's already existing. Dialogue and interpretation have an important means of overcoming misconceptions on the way to achieving mutual understanding in the process of becoming an understanding of the concept of art.

Keywords: art, concept of art, Gadamer, Heidegger, philosophy, art work, understanding of art, aesthetic. 